\title{
STRATEGIC PLANNING OF INFORMATION AND TECHNOLOGY SYSTEMS OF INDONESIAN NAVAL ACADEMY
}

\author{
Isnadi ${ }^{1}$, Suparno ${ }^{2}$, I Nengah Putra ${ }^{1}$, Benny Sukandari ${ }^{1}$ \\ ${ }^{1}$ Indonesian Naval Technology College, STTAL. \\ Bumimoro-Morokrembangan, Surabaya 60187, Indonesia \\ ${ }^{2}$ Institute Technology Sepuluh Nopember, ITS \\ Raya ITS, Keputih, Sukolilo, Surabaya 60111, Indonesia
}

\section{ABSTRACT}

Information technology (IT) has an important role in carrying out the functions of universities, so that it can be trusted to increase the efficiency and effectiveness of the academic process lead to the academic services being more maximal as well as supporting the university's business process innovation to develop. The Naval Academy ( $A A L)$ is one of the educational institutions found in the Indonesian Navy and has the task of producing professional Navy officers, possessing current technological mastery capabilities and towards World Class Navy. By referring to the desired results above, AAL uses information technology in conducting teaching and learning activities. The Information System available at the Naval Academy (AAL) is currently not optimal, therefore the authors conducted an analysis to plan the strategic development of information systems and information technology at the Naval Academy ( $A A L)$. This research was made using the Ward and Peppard method. The step of this research started with internal analysis, external analysis using PEST analysis, internal IS/IT analysis and external SI/IT analysis to map the information system position at the Naval Academy (AAL) with SWOT analysis. The results were the achievement of the IS/IT formulation strategy and management of IS/IT in the future.

Keywords: Strategic Planning, Ward and Peppard Method, PEST, SWOT.

\section{INTRODUCTION.}

The development of information technology has now been adopted by many organizations from various fields, including education (Annwareen., 2008). Information technology (IT) also has an important role in carrying out the functions of universities, so that it can be trusted to increase the efficiency and effectiveness of the academic process lead to the academic services being more maximal as well as supporting the university's business process innovation to develop. The maximum IT utilization can be maintained if an evaluation of how far information technology services are utilized was carried out. However, evaluation and control of the IT use are sometimes less noticed by universities so that the availability of IT services becomes less optimal and inappropriate. In order to be able to provide strategic opportunities for universities, the function of information technology needs to be realized and accompanied by a good information technology management (García, 2013). The purpose of the evaluation was to assess, monitor, and ensure that the academic service resources can operate effectively in accordance with the objectives of the university's strategic plan.

The Naval Academy (AAL) is one of the educational institutions found in the Indonesian Navy and has the task of producing professional Navy officers, possessing current technological 
mastery capabilities and towards World Class Navy. By referring to the desired results above, $A A L$ uses information technology in conducting teaching and learning activities. By using IT, students and lecturers will be able to provide learning material without time and space constraints and places for teaching and learning activities. There are 3 information systems in Academic Navy (AAL) that support teaching and learning activities namely Siakad (Academic Information System), Smart Class and CBT (Computer Based Training).

Academic Information System or SIAKAD is an information system that is built and developed with modules contained in it namely the education calendar and there is lecture material that can be taken by students and used at any time. The use of Academic Information Systems is not optimal, including nonoptimal information content, access convenience and system availability that is not in accordance with the users' expectation.

Based on the problems above, it is necessary to have an information system and information technology strategic planning at the Naval Academy ( $A A L)$ that is able to solve current problems and formulate information systems and information technology strategies in the future. This research was made using the Ward and Peppard method. The step of this research started with internal analysis, external analysis using PEST analysis, internal IS/IT analysis and external SI/IT analysis to map the information system position at the Naval Academy (AAL) with SWOT analysis. Based on the background above, the author intended to make research entitled "Strategic Planning Information Systems and Information Technology at the Naval Academy (AAL)".

\section{MATERIALS/METHODOLOGY.}


by developing an Information System Strategy the Business Strategy is also developed.

b. Information System Strategy as the master of the Information System function where the Information System strategy focuses on strategies to run an Information System efficiently and effectively. The Information System Strategy has 2 objectives, first is identifying the $\mathrm{SI}$ assets needed, including the parties involved such as $\mathrm{SI}$ employees and their abilities, the structures involved in the SI process, financial capabilities for $\mathrm{SI}$, and the second is allocating existing $\mathrm{SI}$ assets in a way that most effectively.

c. Information System Strategy and views in organizations about the role of Information Systems, namely a shared understanding of the role of the SI between business and $\mathrm{SI}$ functions that provides a basis for forming organizational perspectives on how to invest and utilize SI for strategic purposes.

\subsection{Strategy Of Information Technology}

According to (Ward and Peppard, 2002), Information Technology specifically refers to technology, hardware, software, and telecommunications networks. In this case, it concerns tangible assets such as servers, personal computers, routers, and other hardware, and intangible assets such as software. IT facilities include the acquisition, storage, delivery and sharing of information and other digital content.

So information technology strategies related to how the organization's demand for information and systems will be supported by technologies such as IT capabilities, IT infrastructure, IT operational services, and system development services and support for users.

\subsection{Strategical Plan}

According to Ward, (Ward and Peppard, 2002) in his book Strategic Planning For Information Systems, strategic planning is a process of identifying, evaluating, and deciding strategies that can be called strategy formulations. The process of determining how to achieve this strategy is performed by planning a number of actions needed and developing resources effectively.

Strategic planning is an organizational management activity that is used to set priorities, focus energy and resources, strengthen operating facilities, ensure that employees and other stakeholders work towards the same goal, build mutual agreement on the desired results, and assess and adjust organizational objectives facing environmental change.

\subsection{IS/IT Planning Process}

According to (Ward and Peppard, 2002), IS / IT strategic planning must be based on internal and external business environments as well as internal and external $I S / I T$, then the data will be analyzed in the IS/IT strategy process. Through the IS/IT strategy process, several $\mathrm{SI}$ business strategies, IS/IT management strategies, and IT strategies will be produced. The three results of the IS/IT strategy process are then analyzed and produce into a portfolio of applications for the coming period. The portfolio will be used as the basis for developing information systems for future companies. The portfolio developed in the development of the information system will later affect the internal IS/IT environment of 
the Company. Figure 2.1 illustrates the IS / IT strategic planning process.

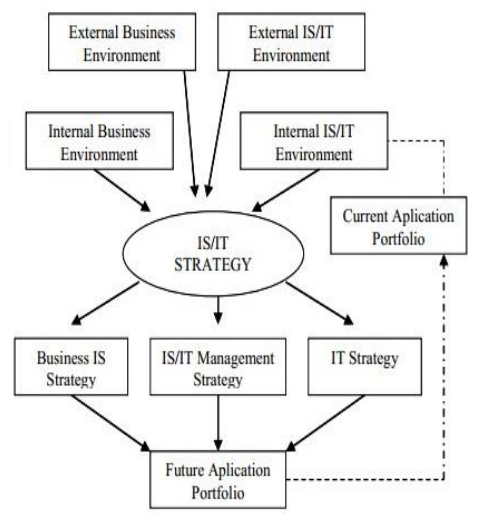

Fig 1. 1IS/IT Strategical Plan Process

(Ward and Peppard, 2002)

The following is an explanation related to the stages of Figure 2.1, namely:

a. Input, as input in strategic planning systems and information technology, which consists of:

\section{a) External Business Environment}

Current business strategies, goals, resources, processes and culture and the value of a business.

b) Internal Business Environment

Economy, industry and competitor's claims.

c) Internal IS/IT Environment

The current IS / IT perspective on business, the scope, and contribution of business, skills, resources and technology infrastructure.

d) External IS/IT Environment

1.1

Technology trends and opportunities related to the use of IS / IT used by other actors, such as consumers, competitors, and suppliers.

b. IS / IT Strategy, namely the process of processing information obtained from inputs resulted in output.

c. Output, consists of:

1) Business IS Strategy, namely how IS/IT will be built in each unit or function to achieve business goals. In addition, each application portfolio will be developed for each business unit and business model which describes the information architecture for each unit. In the portfolio, it is possible to enter what IS/IT will be used in the future to achieve the objectives of a business unit.

2) IS/IT Management Strategy, common elements in the strategy that will be used by the entire organization to ensure consistency of the policy when needed.

3) IT Strategy, policies and strategies to regulate technology and specific resources that will be managed and developed to meet business IS strategies.

4) Future Application Portfolio, namely details about the proposed application that will be used in the future, to integrate each unit and adjust technological developments with the development of the company.

5) Current Application Portfolio, Namely details on the application of information systems applied by the current company by looking at the advantages and strengths obtained and seeing the application support for operational activities and system strategies planning and information technology for the company.

\subsection{SWOT Analysis}

SWOT analysis is a systematic identification of various factors to formulate a company's strategy. This analysis is a process to identify internal (strength and weakness) and external factors (opportunity and threat) from the organization systematically to formulate organizational strategies (Rangkuti, 2004). This analysis is used to evaluate strengths, weaknesses, 
opportunities, and threats in a project or business speculation. This process involves determining the specific goals of business or project speculation and identifying internal and external factors that support and which are not in achieving that goal.

a. Strength; internal actors who support the company in achieving its objectives. Supporting factors can be in the form of resources, expertise, or other advantages that may be obtained due to financial resources, image, excellence in the market, and good relations between buyers and suppliers.

b. Weakness; internal factors that prevent the company from achieving its goals. The inhibiting factor can be in the form of incomplete facilities, lack of financial resources, management ability, marketing expertise, and corporate image.

c. Opportunity; external factors that support the company in achieving its objectives. External factors that support the achievement of goals can be in the form of policy changes, competition changes, technological changes and the development of supplier and buyer relationships.

d. Threat; external factors that prevent the company from achieving its goals. External factors that hinder companies can be the entry of new competitors, slow market growth, increased bargaining power from major suppliers and buyers, technological changes and new policies.

\subsection{PEST Analysis}

PEST analysis is an analysis of external business environment factors that cover the political, economic, social and technological fields. (Ward and Peppard, 2002)

\section{a. Political Factor}

Political factors include government policies, legal issues, and include formal and informal rules of the environment in which the company carries out its activities, for example:

1) Tax Policy

2) Labor regulations

3) Regional regulations

4) Trade regulations

5) Political stability

\section{b. Economic Factor}

Economic factors include all factors that affect the purchasing power of customers and influence the climate of the business of a company, for example:

1) Economic growth

2) Interest rates

3) Exchange rate standards

4) Inflation rate

5) Prices of products and services

\section{c. Social Factor}

Social factors include all factors that can affect the needs of customers and influence the size of the existing market share, for example:

1) Level of community education

2) Level of population growth

3) Social environment conditions

4) Working environment conditions

5) Safety and social welfare

\section{d. Technological Factor}

Technological factors include all things that can help in facing business challenges and support the efficiency of business processes, for example:

1) Technology research and development activities 
2) Automation

3) The speed of technology transfer

4) Technology expiration rates

PEST is used to assess the market from a business unit or organizational unit. PEST analysis is a framework for assessing a situation, and assessing a strategy or position, company direction, marketing plan, or idea. This analysis is enough to affect the company, because a new

opportunity or threat can be taken for the company through this analysis.

\section{RESEARCH METHOD.}

This research is qualitative research. In this section, we will explain the steps used in information system strategic planning at the Naval Academy (AAL). The steps consist of literature study, data collection, analysis of agency's internal and external environment, formulating agency strategies and making future application portfolios seen in the picture as follows:

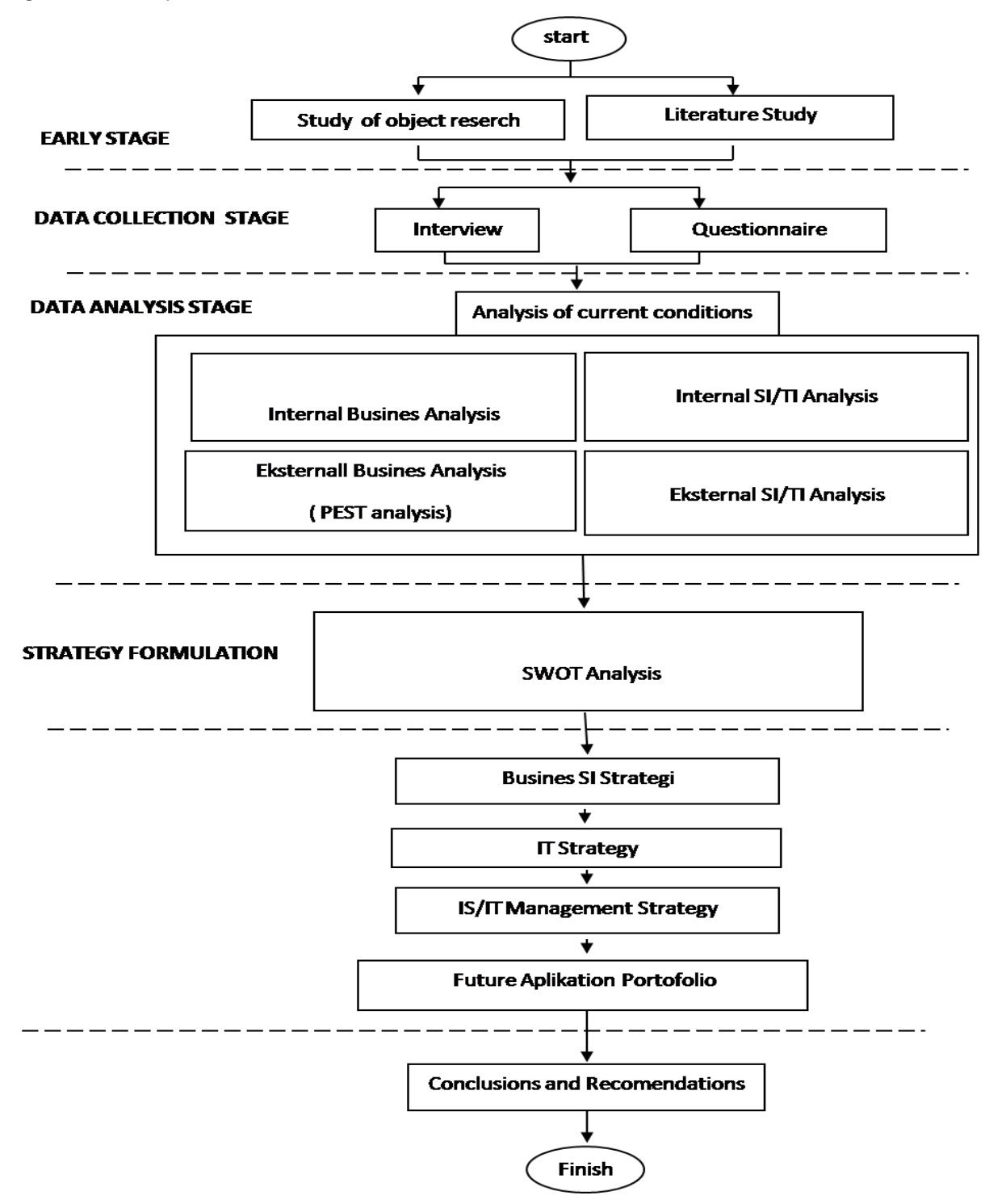

Fig. 2.1. Research Method

4. ANALYSIS AND DISCUSSION.

\subsection{Internal Condition Analysis}

Analysis of AAL the internal conditions regarding the state of information systems 
and information technology viewed from several aspects of indicators include:

a. Factors of the Naval Academy Information System

The information system at $A A L$ currently exists, but there is no connection between one system and the other. This resulted in students and educators not being able to maximize the information system facilities that had been developed.

Information systems that exist today and have been used to have three information systems, including:

1) SIAKAD (Academic Information System)

2) SMART CLASS

3) CBT (Computer Based Training)

Therefore, the solution of existing analysis is to integrate the three information systems into SIM INTEGRA (Integration Information System) AAL, so that continuity and harmony occur and it will be the convenience for both users and educators.

b. Facto of SI/IT human resource representative
The currently available $\mathrm{HR}$ as a representative as well as the person in charge of running IS/IT within AAL is very limited. As a satker (work unit) appointed by the office, namely: Infolahta Sub-Directorate under the Directorate of Planning and Development, has personnel no more than 13 personnel. This is very unlikely because not all existing personnel has standardization as IS/IT guards. And for SI/IT guards in each department, each study program only has 1 to 2 personnel. And even then, it is not as its main task as a representative but only as a task and responsibility other than its main duties.

\subsection{External Condition Analysis}

To find out the external conditions that can influence the strategic plan of information system development at the Naval Academy, PEST analysis can be PERFORMED where the results of this analysis will be used as a reference to determine the strategy for achieving organizational goals. The results of this analysis were obtained from interviews, obtained results in table 4.1 below:

Table 0.1. PEST Analysis

\begin{tabular}{|c|l|}
\hline ASPECT & \multicolumn{1}{|c|}{ ANALYSIS RESULT } \\
\hline POLITIC/LAW & $\begin{array}{l}\text { Supported by Law No.11 of 2008 concerning Information and } \\
\text { Electronic Transactions (UU ITE) }\end{array}$ \\
\hline ECONOMY & $\begin{array}{l}\text { The budget is supported to develop and maintain systems } \\
\text { that already exist and are running now. }\end{array}$ \\
\hline SOCIAL & $\begin{array}{l}\text { Internet media as a medium for communication sociologically } \\
\text { formed a new community in cyberspace. And a lot it also } \\
\text { formed hacker communities who wanted to make computer } \\
\text { users anxious. }\end{array}$ \\
\hline TECHNOLOGY & $\begin{array}{l}\text { The availability of support for IT infrastructure from the } \\
\text { government }\end{array}$ \\
\hline
\end{tabular}

\subsection{Strategy Formulation}

The formulation of this strategy used a SWOT analysis to obtain a map of strengths and weaknesses as well as threats and opportunities they have. 
In addition, this analysis was also used to find out the best ways to use resources that take into account the internal and external situation of the agency and to build a resource base in the future.

The results of the internal-external and internal-external conditions of IS / IT comprehension that had been done previously were then mapped systematically in the form of strengths, weakness, opportunities, and threats mapping based on the key success factors obtained from the previous analysis. In a row, the SWOT analysis mapping is presented in tables 4.1 and 4.2 along with the sources of the analysis

Table 4.2. Internal Strategical Factor

\begin{tabular}{|c|l|}
\hline & \multicolumn{1}{|c|}{ Internal Strategical Factor } \\
\hline Code & \multicolumn{1}{|c|}{ STRENGTHS } \\
\hline S1 & Have a clear vision and mission goals \\
\hline S2 & Data center room security facilities \\
\hline S3 & The budget is fully supported \\
\hline S4 & Having personnel who have high loyalty \\
\hline & \\
\hline W1 & Systems and procedures that are still manual \\
\hline W2 & The information system is not yet integrated \\
\hline W3 & The database is still separated \\
\hline W4 & Not all of them use Optical Fiber Cables \\
\hline W5 & IT personnel are still limited \\
\hline W6 & Don't have an information system strategic planning blueprint \\
\hline W7 & Dependence with 3rd party \\
\hline W8 & The absence of Governance according to COBIT standards \\
\hline
\end{tabular}

Table 4.3. External Strategical Factor

\begin{tabular}{|c|l|}
\hline Code & \multicolumn{1}{|c|}{\begin{tabular}{c}
\multicolumn{1}{|c|}{ External Strategical Factor } \\
OPPORTUNITIES
\end{tabular}} \\
\hline O1 & $\begin{array}{l}\text { Supported by Law No.11 of 2008 concerning Information and } \\
\text { Electronic Transactions (UU ITE) }\end{array}$ \\
\hline O2 & $\begin{array}{l}\text { Partnership and collaboration with institutions outside the } \\
\text { Indonesian Navy }\end{array}$ \\
\hline O3 & $\begin{array}{l}\text { The budget is supported to develop and maintain systems that } \\
\text { already exist and are running now. }\end{array}$ \\
\hline T1 & \multicolumn{1}{|c|}{ THREATS } \\
\hline T2 & $\begin{array}{l}\text { Less optimal use of ICT in supporting administrative activities } \\
\text { between offices, schools, and other parties. }\end{array}$ \\
\hline T3 & Cyber Crime \\
\hline
\end{tabular}

Based on the factors that have been analyzed before, the determination of the weight was determined by questionnaire survey. Where the party was asked to fill in value from 1 to 5 . Where the smaller value 
Table 4.4. Survey Results of Internal Strategic Factor

\begin{tabular}{|c|c|c|c|c|c|c|c|c|}
\hline & \multirow{2}{*}{$\begin{array}{l}\text { VARIABLE } \\
\text { STRENGTH }\end{array}$} & \multicolumn{3}{|c|}{$\begin{array}{l}\text { QUESTIONNAIRE } \\
\text { SURVEY }\end{array}$} & \multicolumn{3}{|c|}{$\begin{array}{l}\text { QUESTIONNAIRE } \\
\text { SURVEY }\end{array}$} & \multirow{2}{*}{$\begin{array}{l}\text { AVERAGE OF } \\
\text { WEIGHT }\end{array}$} \\
\hline & & 1 & 2 & 3 & 1 & 2 & 3 & \\
\hline S1 & $\begin{array}{l}\text { Have a clear vision and } \\
\text { mission goals }\end{array}$ & 3 & 3 & 3 & 0,083 & 0,075 & 0,083 & 0,081 \\
\hline S2 & $\begin{array}{l}\text { Data center room security } \\
\text { facilities }\end{array}$ & 3 & 4 & 3 & 0,083 & 0,100 & 0,083 & 0,089 \\
\hline S3 & The budget is fully supported & 3 & 3 & 3 & 0,083 & 0,075 & 0,083 & 0,081 \\
\hline \multirow[t]{3}{*}{ S4 } & $\begin{array}{l}\text { Having personnel who have } \\
\text { high loyalty }\end{array}$ & 3 & 3 & 3 & 0,083 & 0,075 & 0,083 & 0,081 \\
\hline & Sub Total Strength & & & & & & & \\
\hline & WEAKNESS & & & & & & & \\
\hline W1 & $\begin{array}{l}\text { Systems and procedures that } \\
\text { are still manual }\end{array}$ & 3 & 3 & 3 & 0,083 & 0,075 & 0,083 & 0,081 \\
\hline W2 & $\begin{array}{l}\text { The information system is not } \\
\text { yet integrated }\end{array}$ & 3 & 3 & 3 & 0,083 & 0,075 & 0,083 & 0,081 \\
\hline W3 & The database is still separated & 3 & 3 & 3 & 0,083 & 0,075 & 0,083 & 0,081 \\
\hline W4 & $\begin{array}{l}\text { Not all of them use Optical } \\
\text { Fiber Cables }\end{array}$ & 3 & 4 & 2 & 0,083 & 0,100 & 0,056 & 0,080 \\
\hline W5 & IT personnel are still limited & 3 & 4 & 4 & 0,083 & 0,100 & 0,111 & 0,098 \\
\hline W6 & $\begin{array}{l}\text { Don't have an information } \\
\text { system strategic planning } \\
\text { blueprint }\end{array}$ & 3 & 3 & 3 & 0,083 & 0,075 & 0,083 & 0,081 \\
\hline W7 & Dependence with 3rd party & 3 & 4 & 2 & 0,083 & 0,100 & 0,056 & 0,080 \\
\hline \multirow[t]{2}{*}{ W8 } & $\begin{array}{l}\text { The absence of Governance } \\
\text { according to COBIT standards }\end{array}$ & 3 & 3 & 4 & 0,083 & 0,075 & 0,111 & 0,090 \\
\hline & subtotal weakness & 39 & 43 & 39 & & & & 1 \\
\hline
\end{tabular}

Table 4.5. Survey Results of External Strategic Factor

\begin{tabular}{|c|l|c|c|c|c|c|c|c|}
\hline & \multicolumn{1}{|c|}{ VARIABLE } & \multicolumn{3}{c|}{ SURVEY } & \multicolumn{3}{c|}{$\begin{array}{c}\text { QUESTIONNAIRE } \\
\text { SURVEY }\end{array}$} & $\begin{array}{c}\text { AVERAGE } \\
\text { OF } \\
\text { WEIGHT }\end{array}$ \\
\hline & \multicolumn{1}{|c|}{ OPPORTUNITIES } & $\mathbf{1}$ & $\mathbf{2}$ & $\mathbf{3}$ & $\mathbf{1}$ & $\mathbf{2}$ & $\mathbf{3}$ & 0,184 \\
\hline O1 & $\begin{array}{l}\text { Supported by Law No.11 of 2008 } \\
\text { concerning Information and } \\
\text { Electronic Transactions (UU ITE) }\end{array}$ & 3 & 3 & 3 & 0,176 & 0,188 & 0,188 & 0,184 \\
\hline O2 & $\begin{array}{l}\text { Partnership and collaboration with } \\
\text { institutions outside the Indonesian } \\
\text { Navy }\end{array}$ & 3 & 3 & 3 & 0,176 & 0,188 & 0,188 & 0,184 \\
\hline 03 & $\begin{array}{l}\text { The budget is supported to develop } \\
\text { and maintain systems that already } \\
\text { exist and are running now. }\end{array}$ & 3 & 3 & 3 & 0,176 & 0,188 & 0,188 & 0,184 \\
\hline \multicolumn{1}{|c|}{ subtotal opportunities } & & & & & & & \\
\hline TH1 & $\begin{array}{l}\text { Less optimal use of ICT in } \\
\text { supporting administrative activities }\end{array}$ & 3 & 3 & 3 & 0,176 & 0,188 & 0,188 & 0,184 \\
\hline T2 & $\begin{array}{l}\text { Less optimal use of ICT } \\
\text { incoordination and communication } \\
\text { between offices, schools, and other } \\
\text { parties. }\end{array}$ & 2 & 2 & 2 & 0,118 & 0,125 & 0,125 & 0,123 \\
\hline
\end{tabular}




\begin{tabular}{|c|l|c|c|c|c|c|c|c|}
\hline T3 & Cyber Crime & 3 & 2 & 2 & 0,176 & 0,125 & 0,125 & 0,142 \\
\hline & subtotal threats & 17 & 16 & 16 & & & & 1 \\
\hline
\end{tabular}

Weight is the important percentage of a variable or indicator in an organization or company. While the rating is determined from the assessment given to conditions or conditions that have been running in the organization or company.

Determination of rating values from 1 to 4 was made based on the results of the researcher's analysis on the condition of the company when conducting interviews and observations of the running process. Giving a rating for a factor that is classified as a strength factor is positive (large strength is given a rating of +4 , whereas if a small strength is given $a+1$ rating). Giving a rating of weakness (weakness) is the opposite, if the weakness is very large, give a rating of 1 and if the weakness is small, the rating is 4 .

Table 4.5. Internal Strategy Calculation and Mapping

\begin{tabular}{|c|c|c|c|c|}
\hline & $\begin{array}{c}\text { VARIABLE } \\
\text { STRENGTH }\end{array}$ & $\begin{array}{l}\text { AVERAGE OF } \\
\text { WEIGHT }\end{array}$ & RATING & $\begin{array}{l}\text { WEIGHT X } \\
\text { RATING }\end{array}$ \\
\hline S1 & $\begin{array}{l}\text { Have a clear vision and } \\
\text { mission goals }\end{array}$ & 0,081 & 4 & 0,322 \\
\hline S2 & $\begin{array}{l}\text { Data center room security } \\
\text { facilities }\end{array}$ & 0,089 & 3 & 0,267 \\
\hline S3 & $\begin{array}{l}\text { The budget is fully } \\
\text { supported }\end{array}$ & 0,081 & 2 & 0,161 \\
\hline \multirow[t]{3}{*}{ S4 } & $\begin{array}{l}\text { Having personnel who } \\
\text { have high loyalty }\end{array}$ & 0,081 & 3 & 0,242 \\
\hline & Sub Total Strength & & & 0,992 \\
\hline & WEAKNESS & & & \\
\hline W1 & $\begin{array}{l}\text { Systems and procedures } \\
\text { that are still manual }\end{array}$ & 0,081 & 3 & 0,242 \\
\hline W2 & $\begin{array}{l}\text { The information system is } \\
\text { not yet integrated }\end{array}$ & 0,081 & 3 & 0,242 \\
\hline W3 & $\begin{array}{l}\text { The database is still } \\
\text { separated }\end{array}$ & 0,081 & 3 & 0,242 \\
\hline W4 & $\begin{array}{l}\text { Not all of them use } \\
\text { Optical Fiber Cables }\end{array}$ & 0,080 & 3 & 0,239 \\
\hline W5 & $\begin{array}{l}\text { IT personnel are still } \\
\text { limited }\end{array}$ & 0,098 & 4 & 0,393 \\
\hline W6 & $\begin{array}{l}\text { Don't have an information } \\
\text { system strategic planning } \\
\text { blueprint }\end{array}$ & 0,081 & 3 & 0,242 \\
\hline W7 & $\begin{array}{l}\text { Dependence with 3rd } \\
\text { party }\end{array}$ & 0,080 & 3 & 0,239 \\
\hline \multirow[t]{3}{*}{ W8 } & $\begin{array}{l}\text { The absence of } \\
\text { Governance according to } \\
\text { COBIT standards }\end{array}$ & 0,090 & 2 & 0,180 \\
\hline & subtotal weakness & 1 & & 1,775 \\
\hline & $\begin{array}{l}\text { X-AXIS COORDINATE } \\
\text { (STRENGHT - } \\
\text { WEAKNESS) }\end{array}$ & & & $-0,783$ \\
\hline
\end{tabular}


Table 4.6. Internal Strategy Calculation and Mapping

\begin{tabular}{|c|c|c|c|c|}
\hline & VARIABLE & \multirow{2}{*}{$\begin{array}{l}\text { AVERAGE OF } \\
\text { WEIGHT }\end{array}$} & \multirow{2}{*}{ RATING } & \multirow{2}{*}{$\begin{array}{l}\text { WEIGHT } X \\
\text { RATING }\end{array}$} \\
\hline & OPPORTUNITIES & & & \\
\hline 01 & $\begin{array}{l}\text { Supported by Law No. } 11 \text { of } 2008 \\
\text { concerning Information and } \\
\text { Electronic Transactions (UU ITE) }\end{array}$ & 0,184 & 4 & 0,735 \\
\hline $\mathrm{O} 2$ & $\begin{array}{l}\text { Partnership and collaboration with } \\
\text { institutions outside the Indonesian } \\
\text { Navy }\end{array}$ & 0,184 & 4 & 0,735 \\
\hline \multirow[t]{3}{*}{03} & $\begin{array}{l}\text { The budget is supported to } \\
\text { develop and maintain systems that } \\
\text { already exist and are running now. }\end{array}$ & 0,184 & 3 & 0,551 \\
\hline & subtotal opportunities & & & 2,022 \\
\hline & THREATS & & & \\
\hline T1 & $\begin{array}{l}\text { Less optimal use of ICT in } \\
\text { supporting administrative activities }\end{array}$ & 0,184 & 2 & 0,368 \\
\hline T2 & $\begin{array}{l}\text { Less optimal use of ICT } \\
\text { incoordination and communication } \\
\text { between offices, schools, and } \\
\text { other parties. }\end{array}$ & 0,123 & 2 & 0,245 \\
\hline \multirow[t]{3}{*}{ T3 } & Cyber Crime & 0,142 & 2 & 0,284 \\
\hline & subtotal threats & 1 & & 0,897 \\
\hline & $\begin{array}{l}\text { Y-AXIS COORDINATES } \\
\text { (OPPORTUNITIES - THREATS) }\end{array}$ & & & 1,125 \\
\hline
\end{tabular}

Based on the difference in the amount between strengths - weak and opportunities threats, it was then mapped into SWOT coordinates to determine the position of Disinfolahta Koarmada II and the results are presented in tables 4.5 and 4.6. It is found that the AAL Subdisinfolahta was at the coordinates $(-0.783 .1,125)$, thus the strategy will be focused on the WO strategy that focuses on correcting existing weaknesses by utilizing the opportunities that arise.

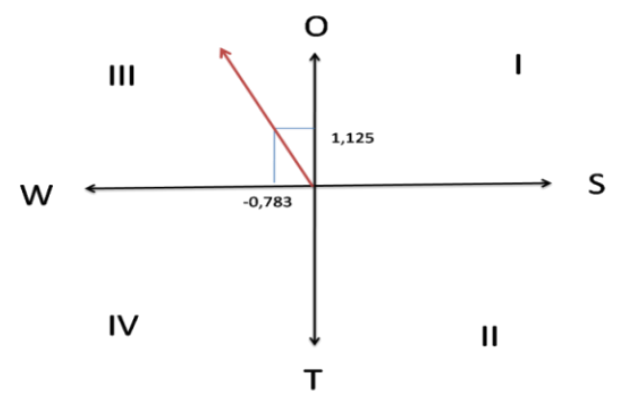

Fig. 4.1. SWOT Diagram of Subdisinfolahta AAL

\subsection{Strategy Formulation}

Formulation of the Navy Academy IS/IT management strategy in the form of restructuring the IS/IT function so that it has strategic value in AAL. In addition, the development of IS/IT human resource competency in AAL is also proposed in the form of improving the quality of competencies through education planning and IT HR training 
policies both internally and externally, performed by AAL agency organizations.

a). The IT AAL Management Strategy can be categorized as follows:

1) Arsitektur Jaringan Komputer dan Keamanan AAL. Prinsip

Computer Network Architecture and AAL Security. Design principles, including network capacity, network reliability, network security, network management, network availability. Network Security Mechanism, anti-virus, mechanism of the relationship between buildings.

2) Database Architecture, including scalability, reliability, stability, availability, multiplatform, security, and capacity.
3) Hardware infrastructure, including peripheral, internal user, server and network needs

b). The Information System Management Strategy at the Naval Academy is a strategy for gathering and identifying strategic needs of $A A L$ and translating it into Information System solutions that support business strategies to achieve the objectives of AAL. In the IS AAL strategy, identification of information system needs is based on the problem. Based on these steps, the system information obtained is needed as follows:

Strategic Planning Formulation has objectives in each of the available indicator fields, here is the data codification of the objectives of the Information Systems and Information Technology Strategy Planning at the Naval Academy:

Table 4.7. The Information System and Information Technology Strategy Planning Objectives at AAL

\begin{tabular}{|c|l|}
\hline Code & \multicolumn{1}{|c|}{$\begin{array}{c}\text { The Information System and Information Technology Strategy } \\
\text { Planning Objectives at AAL }\end{array}$} \\
\hline PS1 & Creating a well-integrated system \\
\hline PS2 & Internalization of Academic and Character Values and Military Doctrine \\
\hline PS3 & $\begin{array}{l}\text { Building a model and Leadership Development System in Organizational } \\
\text { Structure }\end{array}$ \\
\hline PS4 & Building Collaboration with Universities and Institutions outside of service \\
\hline PS5 & Improve Products from Courses, Training, and Parenting \\
\hline PS6 & Increase the strength of financial support \\
\hline PS7 & Making quality assurance institutions in the internal environment of the AAL \\
\hline PS8 & Improving the Quality of Education: Taruna and Taruni \\
\hline PS8 & Improving the Quality of Educators and Increasing Honorarium \\
\hline PS9 & Building Information and Technology Infrastructure \\
\hline
\end{tabular}

There are a number of things that the analysis wants to strive for as a target for
Strategic Planning Information Systems and Information Technology include the following:

Table 4.8. Information Strategy Planning Target

\begin{tabular}{|c|l|}
\hline Code & Information Strategy Planning Targets of Information System and Information \\
\hline SS1 & The realization of the similarity and efficiency of data processing information systems \\
\hline SS2 & The Realization of Utilization Unity of Information System platform \\
\hline SS3 & The realization of a Desktop unity in the Information System \\
\hline SS4 & The realization of good learning management \\
\hline SS5 & The realization of a good performance system \\
\hline SS6 & The Realization of good Infrastructure Development and Improvement \\
\hline SS7 & The realization of good quality IS/IT human resource \\
\hline
\end{tabular}


c) The IS / IT HR Management Strategy

at $A A L$ is designed to improve the quality and improvement of human resources by optimizing existing HR. This increase in HR can be done in various ways, one of them is described below:

Table 4.9. AAL IS/IT Strategic Planning

\begin{tabular}{|c|l|}
\hline Code & \multicolumn{1}{|c|}{ AAL IS/IT Strategic Planning } \\
\hline SDM1 & $\begin{array}{l}\text { Increasing collaboration with universities outside the AAL institution } \\
\text { and collaborating in education and short courses, so that existing HR } \\
\text { can develop and improve their knowledge in IS/IT. }\end{array}$ \\
\hline SDM2 & $\begin{array}{l}\text { Providing opportunities to be able to organize training in the } \\
\text { department. }\end{array}$ \\
\hline SDM3 & Giving Punishment and Reward to successful personnel \\
\hline SDM4 & Get used to always checking networks and systems that are running. \\
\hline SDM5 & $\begin{array}{l}\text { Placement of personnel in a position that is in accordance with their } \\
\text { expertise. }\end{array}$ \\
\hline SDM6 & $\begin{array}{l}\text { Recruitment of personnel who have qualifications and standardization } \\
\text { of IS / IT }\end{array}$ \\
\hline
\end{tabular}

\subsection{ROADMAP}

The Road Map contains an action plan made based on strategic steps that have been taken from strategic planning that will provide guidance and direction to achieve each IS/IT strategy target at AAL. This Road Map is written into a five-year IS/IT policy, with the distribution of the year in accordance with priorities:

Table 4.8. Information Systems and Information Technology Planning Road Map at the Naval Academy

\begin{tabular}{|c|l|}
\hline Year & \multicolumn{1}{|c|}{ The content of The Road Map } \\
\hline $\mathbf{1}^{\text {st }}$ Year & $\begin{array}{l}\text { Develop key operational applications and support } \\
\text { applications, network architecture application system } \\
\text { training, network development planning and procurement of } \\
\text { goods and network administrator training. }\end{array}$ \\
\hline $\mathbf{2}^{\text {nd }}$ Year & $\begin{array}{l}\text { Implementing and maintaining network development, } \\
\text { evaluating IT Plan. }\end{array}$ \\
\hline $\mathbf{3}^{\text {rd }}$ Year & Developing strategic applications \\
\hline $\mathbf{4}^{\text {th }}$ Year & $\begin{array}{l}\text { Training in strategic applications and high potential } \\
\text { application development. }\end{array}$ \\
\hline $\mathbf{5}^{\text {th }}$ Year & $\begin{array}{l}\text { Continuous maintenance and evaluation of information } \\
\text { systems for five years. }\end{array}$ \\
\hline $\mathbf{6}^{\text {th }}$ Year & $\begin{array}{l}\text { Developing FO Backbone and developing Networking in } \\
\text { AAL warriors. }\end{array}$ \\
\hline
\end{tabular}

\section{CONCLUSION.}

\subsection{Conclusion}

Based on the results of this study it can be concluded that: a) In the Information Technology and Information Systems at AAL is currently doesn't have the alignment between existing information systems with other information systems, so it is expected that there is an 
alignment between information systems and information technology. It is because several factors mentioned below:

1) There is no integration between one information system with another information system.

2) The location of information systems, namely in the form of hardware and software, are far from each other (in different buildings).

3) Budget system for developing and maintain the existing and running system has not been able to meet the needs.

4) Qualified human resources are still very minimal.

5) Lack of cooperation and training with external education institutions, resulting in a lack of knowledge in the IS/IT field.

6) The lack of HR personnel as guards and information system operators.

b) The expected condition in this paper is that it can be developed in the form of an information integration system both systematically and the technology used. The information system that is expected to be developed is SIM INTEGRA AAL (Naval Academy Integration Information System)

c) Developing a strategic plan and integrate the three information systems. The design of the IS/IT management strategy is in the form of:

1) Restructuring the organizational functions of the AAL Sub Directorate of Infolahta so that it has strategic value. Besides that, it was also proposed:

2) The Need for System Integration which leads to the development of SIM INTEGRA AAL

3) Conducting Coordination with the Center namely TNI Headquarters to develop this information system. d) Creating a clear Road Map as a reference for the development of IS/IT going forward for AAL.

\subsection{Recommendation}

a) Development of IS/IT human resource Competencies in the form of improving the quality of competencies through official policies in the Navy unit. IT HR education and training planning will be performed both internally and externally by AAL agency organizations.

b) Computer / Networking Network Repair

c) Renewal of Server and Computer equipment, as supporting the operation of an information system.

d) The convenience in administration of maintenance cost.

e) Added quota/internet bandwidth at AAL.

f) Addition of qualified IS / IT personnel

\section{BIBLIOGRAPHY}

Annwareen. (2008) Information Technology in an Organization's Management.

Chen, D. (2010) Information Systems Strategy: Reconceptualization, Measurement, and Implications, MIS Quarterly.

García, V.V..D.E.J.F.V..D.L.U.A. (2013) 'Maturity Model for IT Service Outsourcing in Higher Education Institutions', vol. 4, No. 10.

Laudon., K.C. (2013) Management Information Systems: Managing the Digital Firm 13, London: Pearson Education. 
Obrien, J.A. and M.Marakas., G. (2010) Management Information Systems, New York: McGraw-Hill.

Rangkuti, F. (2004) Analisis SWOT Teknik Membedah Kasus Bisnis, jakarta: PT. Gramedia Pustaka Utama.

Ward, J. and Peppard, J. (2002) Strategic Planning for Information System., West Sussex: John Wiley \& Sons Ltd. 